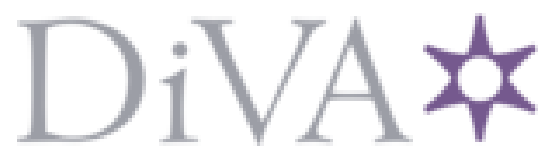

http://www.diva-portal.org

This is the published version of a paper published in Journal of Intellectual Disability - Diagnosis and Treatment.

Citation for the original published paper (version of record):

Adolfsson, M., Westerberg, C., Möller, K. (2014)

Everyday Life Situations of School-Aged Children with Severe Disabilities: What are the Goals for the Future? An Exploratory Study.

Journal of Intellectual Disability - Diagnosis and Treatment, 2(1): 21-32

http://dx.doi.org/10.6000/2292-2598.2014.02.01.3

Access to the published version may require subscription.

N.B. When citing this work, cite the original published paper.

Open Access journal: http://www.lifescienceglobal.com/journals/journal-of-intellectual-disabilitydiagnosis-and-treatment

Permanent link to this version:

http://urn.kb.se/resolve?urn=urn:nbn:se:hj:diva-25191 


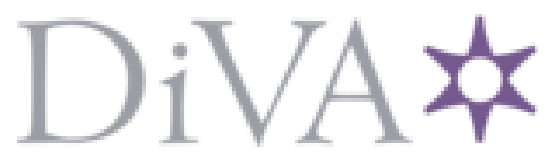

http://www.diva-portal.org

This is the published version of a paper published in Journal of Intellectual Disability - Diagnosis and Treatment.

Citation for the original published paper (version of record):

Adolfsson, M., Westerberg, C., Möller, K. (2014)

Everyday Life Situations of School-Aged Children with Severe Disabilities: What are the Goals for the Future? An Exploratory Study.

Journal of Intellectual Disability - Diagnosis and Treatment, 2: 21-32

http://dx.doi.org/10.6000/2292-2598.2014.02.01.3

Access to the published version may require subscription.

N.B. When citing this work, cite the original published paper.

Permanent link to this version:

http://urn.kb.se/resolve?urn=urn:nbn:se:hj:diva-25191 


\title{
Everyday Life Situations of School-Aged Children with Severe Disabilities: What are the Goals for the Future? An Exploratory Study
}

\author{
Margareta Adolfsson ${ }^{1, *}$, Christina Westerberg ${ }^{2}$ and Kerstin Möller ${ }^{3}$
}

${ }^{1}$ CHILD, School of Education and Communication, Jönköping University, The Swedish Institute for Disability Research, Jönköping University, Box 1026, SE-551 11 Jönköping, Sweden

${ }^{2}$ Department of Special Education, Faculty of Social Sciences, Stockholm University, SE-106 91 Stockholm, Sweden

${ }^{3}$ The Swedish Institute for Disability Research, Örebro University, School of Health and Medical Science, Örebro University, The University Hospital, Centre for Audiological Research, Örebro, SE-701 82 Örebro, Sweden

\begin{abstract}
This study investigated present and future everyday life situations (ELS) in home, school, work, and leisure environments for a group of school-aged children with severe disabilities, including complex disorders and a combination of disabilities. The purpose was to explore universal ELS; clarify how the children can be supported in their development of autonomy; and to gather information on potential overall goals for interventions. To make data comparable, all reported ELS were linked to the International Classification of Functioning, Disability and Health, Child and Youth version (ICF-CY) and listed along with information on the setting. Both today, and in the future, recreational activities and participation in school or work were of highest importance, but few reported ELS involved directly interacting with other children. More ELS were predicted to occur outside the home and with a higher degree of autonomy. Therefore, interventions would be focused on the overall goal that children with severe disabilities take initiatives to become independent and to form relationships with others.
\end{abstract}

Keywords: Children, classification, disability, everyday life situation, ICF-CY, involvement, participation, special education.

Everyday Life Situations (ELS) are everyday activities that occur regularly in a child's natural environments. The ELS require more or less complex actions and affect the child's development [1, 2]. Even though desires for involvement in ELS seem nearly the same for all children, children with disabilities are usually at greater risk of limited social involvement [35]. Their involvement may be affected by peer relationship difficulties causing problems mastering the social tasks of gaining entry into peer groups [6]. In addition, children with Severe Disabilities (SD), including complex disorders and a combination of disabilities, need support to carry out daily activities. Therefore, they spend much time with adults and their involvement in ELS often becomes mandated by people around them [7-9]. To facilitate involvement, the children's networks need to intentionally support them in their development of self-determination and autonomy. To get knowledge of the ELS for schoolaged children with SD and clarify how networks can support them in their development of autonomy, the current study intends to explore universal ELS for

*Address correspondence to this author at the P.O. Box 1026, SE-551 11 Jönköping, Sweden; Tel: +46 70 2039306

E-mail: margareta.adolfsson@hlk.hj.se children with SD occurring in present time and envisioned for the future.

\section{INTRODUCTION}

Involvement in ELS means participation. In the interactive health model International Classification of Functioning, Disability and Health, Child and Youth version (ICF-CY), participation is a key construct, described as children's involvement in life situations including a feeling of belonging and engagement $[10$, 11]. The construct incoporates taking part, being included and accepted in ELS but also having access to needed resources. Considering education, participation includes two elements, both related to functioning within a context $[7,12,13]$. First, it is about being in the school setting and attending activities. It includes availability of and access to everyday activities, which adults can ensure based on legislation and the belief that children should go to school every day. Secondly, participation is about engaging while being there, e.g. enjoying lectures and acquiring knowledge. It considers the intensity of children's involvement in activities and reflects how individual children manage and experience demands and events.

Essential parts of learning processes are participation and peer relationships. Therefore, 
occuring ELS are the most critical features of children's experiences during childhood [2, 14]. In school contexts, participation may include a positive interaction among and acceptance by classmates [15]. With respect to children's engagement and how environments constitute affective and motivational aspects of participation, e.g. enjoyment and preference, accommodations are often needed and the ELS should be accepted by the individual child [16-18]. In this regard, the adults must learn what matters most for each child to enhance engagement, support development and facilitate well-being. Everyday learning that is interest-based improves children's engagement also in other activities, making them prepared for different contingencies and gradually responsible for what happens around them.

Severe disabilities are complex and most often include secondary conditions. They might be predictors for developmental and learning difficulties, and for limited involvement. The disorder cerebral palsy $(C P)^{1}$, for example, may include epilepsy; hydrocephalus; visual disturbances; hearing difficulties; neurodevelopmental deficits; communication problems; and learning disabilities [19-21]. In a Swedish study of children with $\mathrm{CP}$, aged 5 to 8 years, participation restrictions were related to mobility, education, and social relations [21]. Epilepsy was found in 35\% and visual impairment in $20 \%$ of these children. The combination of visual disabilities; communication difficulties; motor impairments; and additional impairments have various names including profound intellectual and multiple disabilities; complex communication needs; or multiple disability visual impairment [21-24]. In the current study, a combination of disabilities is labelled as severe disability.

To describe children's functioning, one has to move beyond their disabilities. Previous research has established that functioning is affected by several interacting factors and that medical diagnoses provide information neither on functional status nor on involvement in ELS [10, 25-27]. Instead, functioning is dependent on the interaction between the child with children with SD and the environment. For example, with appropriate technical aids and/or personal support, a child with visual impairment could help in preparing meals and thereby not experience limited social

\footnotetext{
${ }^{1}$ Cerebral palsy describes a group of permanent disorders of the development of movement and posture, causing activity limitations which are attributed to non-progressive disturbances that occurred in the developing fetal or infant brain. 19. Rosenbaum $\mathrm{P}$, et al. A report: the definition and classification of cerebral palsy. Developmental Medicine \& Child Neurology 2007; 49(s109): 814. (p9).
}

involvement in that specific ELS. As involvement is also a matter of getting access to activities, not least physically, children with SD become dependent on Social Support Networks (SSN).

The SSN around children with SD are extensive. They include persons with various roles including nurturing; supporting; educating; and decision making. According to Harty and colleagues [28], the SSN rarely include close friends but up to 65 adults with roles as parents; professionals, such as assistants; teachers; and health professionals in interdisciplinary teams in addition to peripheral partners, such as principals and other decision makers. Over a child's life, transitions change the SSN; natural environments; and ELS [29]. As the children's involvement in ELS is so often dependent on their SSN, low expectations of a the child's skills can inhibit development instead of being facilitating [30, 31]. Some adults might do everything for the child, which can cause learned helplessness. Instead, teaching the child to help himself is an active way to attain independence and autonomy. According to Tellevik and Elmerskog [23], this strategy can be encouraged by educating those in the SSN, using a teaching approach centered on social involvement.

The opportunities for social involvement, including integration and participation for all in the society, are core ideological principles in Swedish disability policy [32]. Ever since 1968, those children with SD have had the right to preschool (1-5 years) and special education in training schools (6-21 years). In addition, various support systems promote equality in living conditions for the children. Those systems should collaborate in identifying and prioritizing individual areas for development and thus for intervention. Although the National Board of Health and Welfare has issued a decree that requests professional collaboration, it appears weak or absent [33, 34].

With the purpose to improve the collaboration among parents and professionals in the SSN around school-aged children with SD in special education, a Participation and Mobility Project (P\&M project) was conducted in Sweden during the years 2008-2011 [23, 35]. The project aimed to test a method to further develop and utilize the skills of the SSN including parents and professionals such as assistants in school and home; teachers; service providers in health care; and decisionmakers. To create conditions for responsible persons to plan, conduct, and evaluate interventions focussing on participation, specific ELS in which children with SD participated were investigated. 
In the P\&M project, the SSN of children with SD were the direct participants whereas the children became indirect participants. The intervention consisted of inservice training conducted as three workshops with the use of a holistic, activity-based teaching approach centered on individual children's involvement in ELS $[23,35]$. The training included five steps: determination of present ELS; future ELS with definition of main goals; prioritization of activities; implemention; and evaluation. As the participants were allowed to freely express ELS, the project results did not indicate any universal ELS for those with children with SD.

\section{Purpose}

The purpose of the current study was to build on the first two steps of the P\&M project ${ }^{2}$ to explore universal ELS for children with SD and how SSN can support the children in their development of autonomy. Future ELS were investigated to get knowledge on potential overall goals for involvement in ELS and thus of importance for decisions of interventions.

\section{Ethical Considerations}

Ethical approval was not applied for this particular study since data were taken from the earlier P\&M project. Since that project had a teaching approach focusing on networks, and no interventions were provided, it did not involve sensitive personal information or physical encroachment on subjects or used any method that affected the subjects physically or psychologically. All participants had consented to the research. Parents gave their written, informed consent for participation including access to patient records and special educators' data [35]. Principals' consent were given for professionals in schools. Interdisciplinary team members were involved based on the parents' desires in addition to individual's consent to participate.

\section{METHODS}

The design was descriptive in nature. Children's ELS in home, school, work, and leisure environments were investigated based on information from SSN of seven Swedish school-aged children with SD 5-19 years. To make data comparable, the information was linked to the International Classification of Functioning, Disability and Health, version for Children and Youth (ICF-CY), using linking rules [10, 36].

\footnotetext{
${ }^{2}$ Data from the first two steps of the P\&M project were available for the current study as its second and third authors had been engaged also in the P\&M
} project.

\section{ICF-CY}

The ICF-CY was used as a framework providing a structure and languge for the description of functioning and involvement in ELS, considering the impact of the environment on a child's functional status.

The ICF-CY coding system enables linkage of information to ICF-CY codes facilitating identification and comparison of data. Linkage can be made to any of four components consisting of chapters including categories listed hierarchically with increasing level of detail, identified by codes with an increasing number of digits $[10,37]$. The four components are Body Structures with anatomical parts; Body Functions including physiological and psychological aspects; Activities and Participation defined as the execution of a task or action and involvement in life situations; and Environmental Factors with physical, social,and attitudinal elements [10].

For the purpose of the current study, the nine chapters in the ICF-CY component Activities and Participation, so called life areas, and the fifth chapter in the component Environmental Factors, specifically health services, were used to identify ELS (Table 1).

\section{Participants}

\section{Children - Indirect Participants}

A sample of included children with SD in the P\&M project had been identified by the six special-needs advisors supporting this group of children at the National Agency for Special Needs Education and Schools (SPSM) [35]. The support offered by SPSM involves individual's learning, the work and activities of teachers, and organizational issues in schools. The advisors have broad knowledge of the pedagogical consequences of disabilities, and the knowledge and skills they offer complement the resoures of the municipalities and schools. For the purpose of the P\&M project, each advisor had been asked to identify children with SD in their area; inform the parents and school principals about the project; and ask them for consent to participate. Inclusion criteria were schoolaged children with severe disability including visual and mobility impairments and receiving on-going support from the special-needs advisor. In addition, the children would be in a transition such as enter school; advance to a higher grade level; begin higher education; begin working; or move to independent living.

Eight children had been identified and initially recruited to the P\&M project. However, as one set of 
Table 1: Chapters in the Two ICF-CY Components Used in this Study

\begin{tabular}{|c|c|c|c|}
\hline Code & Activities and Participation (d) & Code & Environmental factors (e) \\
\hline \hline d1 & Learning and applying knowledge & e1 & Products and technology \\
d2 & General tasks and demands & e2 & Natural environment and human-made changes to \\
d3 & Communication & & Support and relationships \\
d4 & Mobility & e3 & Attitudes \\
d5 & Self-care & e4 & Services, systems and policies \\
d6 & Domestic life & & \\
d7 & Interpersonal interactions and relationships & & \\
d8 & Major life areas & & \\
d9 & Community, social and civic life & \\
\hline
\end{tabular}

parents withdrew from the study at the end of the first year, the current study included seven children from six different regions of Sweden. They ranged in age from 5 to 19 . Three of them were boys and four were girls.

The health status of the children are described below. Information on health conditions, i.e., diagnoses, vision, and intellectual status had been collected from parents and patient records. The SSN had described the children's functional status in terms of physical capacity, communication, and vision. This information was defined and labelled by the researchers as displayed in the appendix. For the purpose of the current study, the functional levels were consolidated into three levels: severe, moderate, and mild difficulty (see Appendix).

\section{Health Conditions}

Three of the children were born premature (week $29,32,33$ ). All seven had congenital injuries or brain injuries acquired in infancy, which affect mental functions. Secondary diagnoses of CP were reported for six of the children: two in four children with tetraplegia ${ }^{3}$ and one in two children with diplegia ${ }^{4}$ had dystonic features ${ }^{5}$, which affect movement functions. Five of the children also had a diagnosis of epilepsy.

\section{Functional Status}

The seven children had multiple disabilities of varying functional levels (Table 2). Four of the seven children had moderate to severe difficulties in all four variables. In addition to physical impairments,

\footnotetext{
${ }^{3}$ Tetraplegia is the most severe type of CP characterized by bilateral spasticity predominating in the upper limbs, almost always in association with severe mental subnormality and microcephaly 20. Aicardi J, Bax M. Cerebral Palsy, in Diseases of the Nervous System in Childhood, Aicardi J, Ed. Mac Keith Press: London 1998; pp. 210-244.

${ }^{4}$ Diplegia is defined as a type of $\mathrm{CP}$ in which the lower limbs are much more affected by spasticity than the arms. (20. Ibid. p217).

${ }^{5}$ Dystonic CP is characterized by sudden, abnormal shifts of general muscle tone, often exhibiting abnormal movements. (20. Ibid. p221).
}

communication, and visual difficulties, four of the children had severe intellectual impairments and two children had mild intellectual impairments. Due to age, the preschooler was not assessed. One child walked with physical support and two children used electrical wheel chairs to aid in locomotion. Three of the children could easily communicate. All children had moderate to severe vision difficulties. The functional status of all seven children does well fit into the concept of children with SD.

\section{Transitional Phase}

One child was entering school for the first time, four were advancing to the next level of education, and two were terminating school to begin work (Table 2).

\section{Social Support Networks - Direct Participants}

Sixty-five adults were included in the seven networks (Table 3). The number of participants in each network varied from 5 to 13 (Md 10). The majority of adults, $55 \% \quad(n=36)$, did not frequently meet the children, whereas $45 \% \quad(n=29)$, including parents, personal assistants, and teachers, daily interacted with the children. The researchers learned that many more professionals worked with these children but did not have permission from their employers to participate.

\section{Procedure}

Given the procedures used during the P\&M project, the two first steps were to determine the ELS in which the children were involved. During the first workshop, teachers carefully defined the construct of ELS and draw attention to the variety of possible ELS. Home, school, work, and leisure were specified as spheres of activity [23]. Thereafter, each child's present ELS and where they occured were jointly identified, named and listed by the SSN. This was followed by a determination of the future ELS that were envisioned 
Table 2: The Children's Functional Levels and Transitional Phases (see Appendix for Description of Levels)

\begin{tabular}{|c|c|c|c|c|c|c|c|}
\hline & Child & Child & Child & Child & Child & Child \\
B & C & 16 & 5 & 18 & 17 & 16 & 12 \\
\hline \hline Age & 19 & Severe & Moderate & Severe & Moderate & Severe & Moderate \\
\hline Physical capacity & Severe & Moderate & Moderate & Mild & Mild & Severe & Mild \\
\hline $\begin{array}{c}\text { Communication } \\
\text { Expressing }\end{array}$ & Severe & Moderate & Moderate & Moderate-Mild & Mild & Severe \\
\hline $\begin{array}{c}\text { Communication } \\
\text { Understanding }\end{array}$ & Sederate & Severe & Severe & Severe & Severe & Severe & Moderate- \\
\hline Vision & Begin work & $\begin{array}{c}\text { Advance to } \\
\text { next grade } \\
\text { level }\end{array}$ & Enter school & $\begin{array}{c}\text { Begin work. } \\
\text { Living on his } \\
\text { own }\end{array}$ & $\begin{array}{c}\text { Advance to } \\
\text { next grade } \\
\text { level }\end{array}$ & $\begin{array}{c}\text { Advance to } \\
\text { next grade } \\
\text { level }\end{array}$ & $\begin{array}{c}\text { Advance to } \\
\text { next grade } \\
\text { level }\end{array}$ \\
\hline Transitional phase
\end{tabular}

Table 3: Participants in the Social Support Networks

\begin{tabular}{|c|c|c|c|c|c|c|c|c|}
\hline & Network A & Network B & Network C & Network D & Network E & Network F & Network G & Sum \\
\hline Parents & 2 & 1 & 2 & 1 & 1 & 1 & 1 & 9 \\
\hline Personal assistants & 1 & 3 & 2 & 3 & 2 & 1 & 0 & 12 \\
\hline Teachers & 0 & 2 & 0 & 2 & 2 & 1 & 1 & 8 \\
\hline Special-educators & 1 & 2 & 4 & 2 & 0 & 2 & 2 & 13 \\
\hline $\begin{array}{l}\text { Professionals in } \\
\text { interdisciplinary } \\
\text { teams }\end{array}$ & 1 & 2 & 3 & 2 & 3 & 2 & 0 & 13 \\
\hline Decision-makers & 2 & 1 & 1 & 0 & 0 & 0 & 0 & 4 \\
\hline Principals & 0 & 0 & 1 & 2 & 2 & 0 & 1 & 6 \\
\hline Sum & 7 & 11 & 13 & 12 & 10 & 7 & 5 & 65 \\
\hline
\end{tabular}

by the SSN as important for the children's involvement. Thinking beyond the present, the envisioned future ELS were added to the lists.

To enable participants to further define ELS, the SSN were asked to complete the lists within a three month timeframe. This occurred while they, supported by the special-needs advisors, decided how to improve involvement of the child, i.e., while they prioritized activities.

\section{Data Analysis}

The initial analysis step was to link data to the ICF$\mathrm{CY}$. The first author assigned all listed ELS, submitted from each SSN, to the most detailed code using linking rules by Cieza et al. [36]. Thereafter, the three authors discussed the linkages. Any changes were made by consensus based on common knowledge of linking processes; the purpose of the P\&M project; and the functioning of the children. During discussions, a coding scheme was created [38] including ambigous expressions of ELS and the following consensus-based considerations additional to the linking rules:

\section{Intention}

The intention of an ELS was considered, e.g. "math" was linked to Learning to calculate (d150), "planning the school day" to Carrying out daily routine (d230), and "playing the piano" was linked to Acquiring skills (d155). ELS intended as treatment, e.g. "music therapy", "pool training", "using a standing aid", and "going to the occupational therapist" were coded as Health services (e580). "Rest" was coded as a lesiure activity (d920) in a home environment, however, it was coded as a treatment (e580) in school settings because children with multiple disabilities often need time to stretch during school time. When an ELS occured in several environments, it generated more than one ICFCY code.

Age

Play activities, e.g. "rocking in a swing", were viewed as a Major life area (d8) for the pre-schooler but 
as Recreation (d9) for the older children. In addition, 'ride a moped' and 'travel by car' were coded as Recreation (d9) when offered as entertainment for children unable to drive themselves due to age or functional status.

\section{Socialization}

Independent of the environment, all ELS related to interaction with others were linked to Interpersonal interactions and relationships (d7).

\section{Transportation}

The destination was considered, e.g. "going to school by bus" was given the code for Using transportation (d470) and Maintaining educational programme (d8201).

A second analysis step was used to list the natural environments where the present ELS took place and where future ELS would take place according to the SSN. As one ELS could appear in two or more contexts, the number of environments became more than the number of ELS.

In a final step, the ELS were reviewed according to how they were formulated by the SSN to determine if they solely considered how the child executed a task or also how involved the child seemed in the ELS.

\section{RESULTS}

\section{Present ELS}

Altogether 259 linkages reflected present ELS (Figure 1). Treatments were defined by 27 linkages $(11 \%)$ and related to the environmental factor of Health services (e580). The remaining ELS were distributed

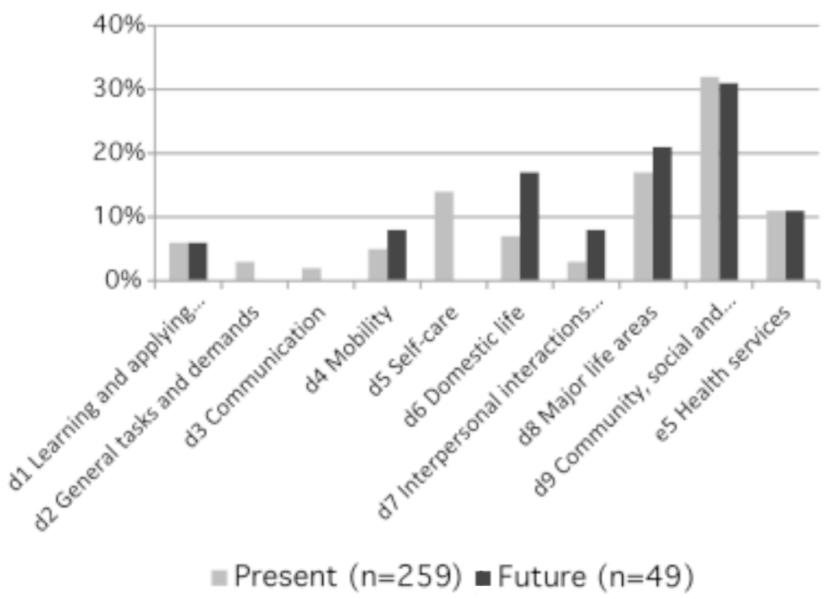

Figure 1: Distribution (\%) of present and future ELS across ICF-CY chapters. across all life areas defined by the Activities and Participation chapters.

Most ELS were associated with three of the nine Activities and Participation chapters: Self-care (d5; $14 \%$ ), such as toileting, dressing or eating; Major life areas (d8; $17 \%)$, such as play, education or work; and Community, social and civic life (d9; $32 \%)$, such as recreational activities. Less ELS were associated with General tasks and demands (d2; $3 \%)$, such as daily routines; Communication (d3; $\%$ ); and Interpersonal interactions and relationships (d7; $3 \%)$, such as relating with peers.

\section{Future ELS}

Altogether 49 linkages reflected future ELS that the networks envisioned (Figure 1). As for the present ELS, $11 \%$ concerned treatment, i.e., Health services (e5). No linkages were made to General tasks and demands (d2); Communication (d3); or Self-care (d5). Proportionally, more linkages were made to Mobility (d4), e.g. managing to enter the school building; Domestic life (d6), e.g. "acquiring a place to live"; Interpersonal interactions and relationsships (d7), e.g. having coffee with a friend; and Major life areas (d8), such as working.

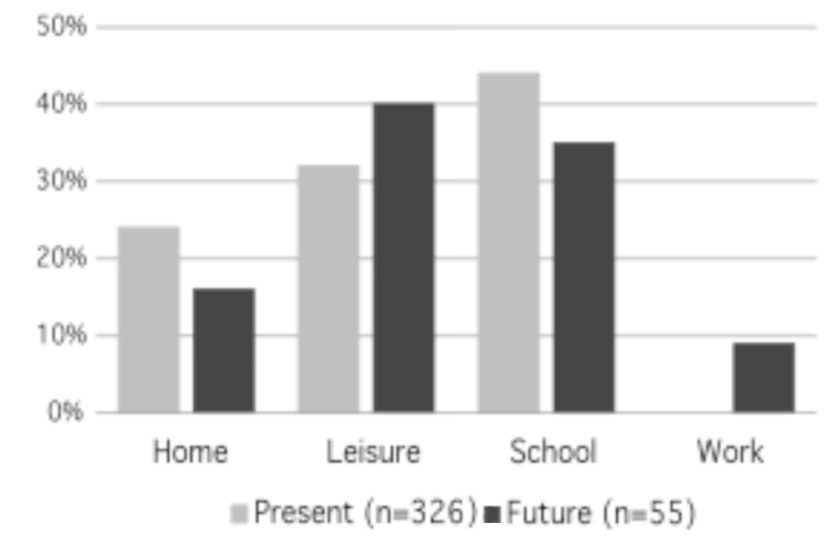

Figure 2: Distribution (\%) of present and future ELS related to environment.

When analyzing the natural environments where the ELS occurred, more envisioned ELS related to leisure time (Figure 2). In the future, work became a natural environment, whereas less envisioned ELS related to home environment and school.

The review of how the ELS were formulated suggested a changed focus, from the execution of a task or action to involvement in ELS with increased independence (Table 4). 
Table 4: Examples of how Everyday Life Situations were Formulated by the Social Support Networks

\begin{tabular}{|c|c|c|c|}
\hline & "Life area" & Present & Future \\
\hline d1 & Learning and applying knowledge & Math; playing the guitar & $\begin{array}{l}\text { Can choose what to do based on weekly } \\
\text { planning }\end{array}$ \\
\hline $\mathrm{d} 2$ & General tasks and demands & Checking today's schedule & -- \\
\hline d3 & Communication & Singing & --- \\
\hline d4 & Mobility & Going to school & $\begin{array}{l}\text { Can find the way using the electrical } \\
\text { wheel chair }\end{array}$ \\
\hline d5 & Self-care & Eating; brushing teeth & --- \\
\hline d6 & Domestic life & Baking; shopping & $\begin{array}{l}\text { Invite someone for coffee; stay in one's } \\
\text { own home }\end{array}$ \\
\hline d7 & $\begin{array}{l}\text { Interpersonal interactions } \\
\text { and relationship }\end{array}$ & Seeing peers & Interact with a friend \\
\hline d8 & Major life areas & Attending group activities & $\begin{array}{c}\text { Participate in activities in the school yard; } \\
\text { engage in work }\end{array}$ \\
\hline d9 & $\begin{array}{c}\text { Community, social and } \\
\text { civic life }\end{array}$ & Listening to music & Participate in sports; go to the pub \\
\hline
\end{tabular}

\section{DISCUSSION}

In this exploratory study, members of Social Support Networks (SSN) of children with Severe Disabilities (SD) have expressed their views about the Everyday Life Situations (ELS) in which children are involved at present time and and will be in the future. The information provides data on how networks can support children in their development of autonomy and can provide guidance for long-term intervention goals. The seven children in the current study ranged in age from 5 to 19 years of age, and all had mobility, communication, and visual impairments. Their self-care activities were foreseen by their SSN to become more automatic and not considered as an ELS in itself in the future. It became obvious that participation is contextrelated and that the children's social inclusion is dependent on the SSN.

For children with SD - as for all children - SSN are essential for their physical and social development and everyday functioning. Children with severe $\mathrm{CP}$, however, may need help to prevent participation restrictions effected by hindering environmental factors such as limited access to objects and events [39]. For the children included in the current study, their SSN identified recreational activities and participation in school or work as being of the highest importance both in present time and in the future. However, few included ELS involved interaction with other children. It was envisioned by the SSN that over time more activities will occur outside the home and with a higher degree of autonomy. Therefore, interventions should be focused on teaching children with SD to take the initiative to become more autonomous and better able to relate to classmates and friends.

Among environmental factors, also society's social attitudes, including low expectations on the children's abilities or self-determination, may constitute participation restrictions $[30,31,40]$. Most of the present ELS were expressed as the execution of tasks, i.e., less complex actions such as morning routines; eating; sleeping; and dressing. The network members also mentioned treatment elements such as 'using a standing aid' as an ELS without adding any activity performed when standing, or 'listening to music' without explaining the context or the relation to peers. One reason can be, consistent with Raghavendra and colleagues [24], that children with SD often attend different activities than other children. This may likely be due to the adult's focus on training which may limit a child's interaction with peers. In special needs education, often children are moved to activities determined and organized by adults. This suggests low expectations of each child's possiblities to express opinions and participate in an active manner $[30,31]$. Given that the same activities are likely to be of interest for children with SD as for other children [3], and that peer relationships are critical to promote any child's development [2], the SSN surrounding children with SD should promote the establishement of peer social interactions.

Social interaction requires that children know and apply their own strengths, preferences, and limitations. Most often, children with SD need support of significant adults to become involved in a degree that is consistent 
with their abilities [41]. All children's capacity of making choices emerges across the life span. When they are capable to stand up for themselves and their rights, they can help create a satisfying way of life [42]. Findings in the current study show convincingly that the SSN were aware of the increasing degree of autonomy. Their envisions for the future indicated a desire to help the children gain independence and provide opportunities to be involved in ELS.

Children's involvement in ELS is a determinant of well-being and life satisfaction and an important factor defining quality of life [43]. Within a group of children with disabilities, involvement may vary due to type of impairment and abilities but also due to the kind of activity, interest and contextual conditions [31, 44]. If the adults believe that children can achieve, it is likely that the children's adaptation to everyday demands improves $[45,46]$. One of the children in the current study, for example, was later allowed to use an electrical wheel chair during school days. It significantly improved her autonomy and independence, and made her free from having an adult close to her all the time. She could draw attention when needed but decide by herself where to move. For children with SD, this opportunity of self-determination also provides understanding of what happens in school; why certain demands are repeated every day; and how to relate to the other children. In the end, it will most likely increase their experience of involvement.

Provided that circumstances are favorable, children with SD can act autonomously within a social framework. With the psychological capacity to make choices and get networks to help them compensate for impaired physical capacity, they can obtain their goals $[30,31]$. A good illustration is a child with severe disability who could not handle tools by himself but decided to create an animal from wood during craft class. After asking his personal assistant to get a piece of wood and begin sawing, the child leaned against the assistant and most likely viewed himself as fulling participating in that activity. It is consistent with Perenboom and Chorus [47] that "Performance in itself does not necessarily refer to participation, while not performing does not necessarily mean that someone is not participating. For instance, participation is also being in control" ( $p 587)$.

Findings raised the question why few ELS included direct interaction with other children or were choosen by the children with SD. One plausible answer is that adults provide 'scaffolds' for children's experiences throughout childhood and therefore arrange ELS that they determine will facilitate child development [30]. However, in addition to having fun and being in control, doing and being with others are elements of participation that most likely facilitate learning and development $[2,17]$. As children with SD usually have little contact and no friendships with children without disablities, they most often communicate with adults and seldom with persons of the same age [28]. Therefore, they need adult support to start interacting with peers and to introduce friendships. Planned and supported relationships among children with disabilities would be the optimal start. In parallell, other children would be coached on how to best interact with children with SD.

Findings also raised the question why so few of the present ELS reflected independent actions although two of the children already were in their late teens. One explanation to this observation could be that interaction or self-selected free activities are not traditionally prioritized in special education. Today, however, the use of Augmentative or Alternative Communication methods (AAC), such as Talking Mats or pressure contacts could support children's selection of activities or desires for peer participation more easily than in the past $[48,49]$. Using AAC in school settings can allow children to indicate their desires and influence the way they dress; in what situations they want to participate; or which children they want to see. Most likely, such communication opportunities may make the children's experiences of ELS move from attend to engage in the activities and support their interactions with other children.

The two dimensions of participation, attend and engage, can be applied to different ecological levels from the degree of participation of a child in a certain ELS in the micro-system to the input of school curricula in the macro-system. Clearly, the network-child interaction is an intrinsic part of the degree to which a child attends school but also part of the degree to which a child engages in specific activities [13, 29]. Therefore, connections among individuals in a child's network are needed to share experiences and agree on what demands to put on the child in different ELS, and how to have the child involved, as regulated on national level. The Swedish Education Act, introduced in 2011 [50], is built on the United Nations Convention on the Rights of the Child [51]. This act includes consideration of the best interests of the child (art. 3) and to children's right to freely express their own views in all matters affecting them (art. 12). To fulfill those 
intentions, children of all ages should be involved in planning and decision making that concern them. As this is not explored in the current study, it is left for future research to investigate how the rights of the education act are applied in special education.

The ELS reported by the networks were mainly correlated with the later chapters in the ICF-CY component Activities and Participation: Self-care (d5); Major life areas (d8); and Community life (d9). The first three chapters showed low representation: Learning and applying knowledge (d1); General tasks and demands (d2); and Communication (d3). These findings support those in previous studies $[1,7,26]$, indicating that the first chapters include basic skills that are important across areas of functioning and constitute prerequisites for involvement in most life situations.

For the purpose of the current study, the ICF-CY worked as the framework for identifying ELS in which children with SD participate. In concordance with the ongoing debate about the construct of participation as context-dependent and closely related to socially and culturally defined roles $[7,15,52]$, the findings showed a strong connection between the childrens' participation and the social environment. As people around children with SD most often mandate their involvement in ELS, it is a challenge for the adults to support the children by acting as facilitators of participation rather than barriers. By this, the adults should help the children to activities in a social context since performing single activities are not part of social participation. In special eduation, the ICF-CY framework can also be used as a diagnostic tool to assess multiple domains to assist in identifying special education needs [27, 53, 54]. The ICF-CY sees disability as a product of activity limitations and participation restrictions that are influenced by environmental and personal factors in addition to impairments. It pinpoints the important role of SSN on children's functioning and participation in ELS.

\section{LIMITATIONS}

In the current study, data were initially collected during the first workshop included in the P\&M project. The SSN had at that occasion recently become acquainted with the constructs of participation and ELS. This might explain the frequency of ELS expressed as performance of tasks, e.g. morning routines; eating; sleeping; and dressing, and the functions required to carry out those tasks or interventions such as using a standing aid. At this initial phase in the holistic teaching process, the present ELS might have been expressed based on what the members of the networks knew that they accomplished with the children rather than on what it meant for the children in terms of participation. Besides, the construct of participation is not entirely clear. The definition is under debate and the interactions with others, including a subjective experience, is not completely ruled by the ICF-CY definition "involvement in life situations" [7, 15]. When linking information, we focused on the children's social roles in the different environments, which might have raised our expectations on social involvement rather than performance of tasks.

Other limitations include: the small sample size; the wide age range; and missing information from professionals who did not participate due to their employers' wishes. Therefore, universal ELS for children with SD could not be established and only tentative conclusions can be drawn.

\section{CONCLUSION}

This exploratory study indicates that recreational activities and participation in school or work are of the highest importance for children with severe disabilities. However, their social support networks seemed to pay little attention to what the present ELS mean for the individual child in terms of interaction or relationships. Over time, ELS were expected to more frequently occur outside the home with a higher degree of autonomy. Therefore, the overall goal for interventions would be that the children with severe disabilities, as much as possible take the initiative to become independent and form relationships with other children. To obtain this goal, the support of the social support network is essential.

Further research should include a larger sample size and examine the opinions of various SSN with respect to the age of the child and their functional status.

\section{ACKNOWLEDGEMENTS}

The current study was supported by the Sunnerdahls handikappfond (Dnr 8/07) and Habilitation services of Dalecarlia, Sweden. The authors also thank the Participation and Mobility project that kindly made the data available for the current study, and Susanne Nelson, Ph.D. Chapel Hill, NC, who thoroughly edited the text. 


\section{Appendix: $\quad$ Functional Levels of Disability}

\begin{tabular}{|c|c|c|c|c|}
\hline $\begin{array}{l}\text { Level of } \\
\text { disability }\end{array}$ & Physical capacity* & $\begin{array}{l}\text { Communication } \\
\text { expressing }^{*}\end{array}$ & $\begin{array}{l}\text { Communication } \\
\text { understanding* }\end{array}$ & $\begin{array}{l}\text { Vision** } \\
\text { Visual acuity, field, } \\
\text { performance and } \\
\text { diagnosis }\end{array}$ \\
\hline 1 & $\begin{array}{l}\text { Severe disability, whole body } \\
\text { affected - head, arms, legs } \\
\text { (poor balance, legs and arms } \\
\text { seriously affected) }\end{array}$ & $\begin{array}{l}\text { Body language - general } \\
\text { moods only expressed } \\
\text { through whole or part of body } \\
\text { or voice, i.e., smile, cry, tense } \\
\text { body, relax }\end{array}$ & $\begin{array}{l}\text { Responds to situations, i.e. } \\
\text { shows pleasure or } \\
\text { displeasure of music, touch, } \\
\text { smell proximity to others but } \\
\text { no specific gesture or word } \\
\text { receives a consistence } \\
\text { response }\end{array}$ & $\begin{array}{c}\text { Blindness/Total visual } \\
\text { impairment. Worse than } \\
0.05\end{array}$ \\
\hline 2 & $\begin{array}{l}\text { Severe disability in legs and } \\
\text { arms (not able to walk and } \\
\text { not able to eat by her/himself) }\end{array}$ & $\begin{array}{l}\text { 1-20 gestures, signs, words, } \\
\text { picture symbols, objects of } \\
\text { reference }\end{array}$ & $\begin{array}{l}\text { 1-20 gestures, signs, words, } \\
\text { picture symbols, objects of } \\
\text { reference }\end{array}$ & $\begin{array}{l}\text { Severe visual impairment. } \\
\text { Worse than } 0.1 \text { but } \\
\text { equal to or better than } 0.05\end{array}$ \\
\hline 3 & $\begin{array}{l}\text { Severe disability in arms (not } \\
\text { able to eat by her/himself). } \\
\text { Minor disabilities in legs (able } \\
\text { to walk) }\end{array}$ & $\begin{array}{l}21-100 \text { gestures, signs, } \\
\text { words, pictures, symbols, } \\
\text { objects of reference }\end{array}$ & $\begin{array}{l}\text { 21-100 gestures, signs, } \\
\text { words, pictures, symbols, } \\
\text { objects of reference }\end{array}$ & $\begin{array}{l}\text { Moderate visual } \\
\text { impairment. Worse than } 0.3 \\
\text { but } \\
\text { equal to or better than } 0.1\end{array}$ \\
\hline 4 & $\begin{array}{l}\text { Minor disabilities in arms } \\
\text { (able to eat by her/himself). } \\
\text { Severe disability in legs (not } \\
\text { able to walk) }\end{array}$ & $\begin{array}{l}\text { Above } 100 \text { signs, words, } \\
\text { picture symbols, objects of } \\
\text { reference but not normal } \\
\text { communication according to } \\
\text { age }\end{array}$ & $\begin{array}{l}\text { Above } 100, \text { signs, words, } \\
\text { picture symbols, objects of } \\
\text { reference but not normal } \\
\text { communication according to } \\
\text { age }\end{array}$ & $\begin{array}{l}\text { Mild visual impairment. } \\
\text { Worse than } 1.0 \text { but } \\
\text { equal to or better than } 0.3\end{array}$ \\
\hline 5 & $\begin{array}{c}\text { Minor disabilities in legs and } \\
\text { arms (able to walk and eat by } \\
\text { her/himself) }\end{array}$ & $\begin{array}{l}\text { Can make some daily needs } \\
\text { known by other means }\end{array}$ & $\begin{array}{l}\text { Can make some daily needs } \\
\text { known by other means }\end{array}$ & No visual impairment \\
\hline 6 & $\begin{array}{l}\text { No disabilities in arms. } \\
\text { Minor disabilities in legs (able } \\
\text { to walk). }\end{array}$ & $\begin{array}{l}\text { Normal communication } \\
\text { according to age }\end{array}$ & $\begin{array}{l}\text { Normal communication } \\
\text { according to age }\end{array}$ & Not applicable \\
\hline 7 & $\begin{array}{l}\text { Minor disabilities in arms } \\
\text { (able to eat by her/himself). } \\
\text { No disabilities in legs }\end{array}$ & Not applicable & Not applicable & Not applicable \\
\hline 8 & $\begin{array}{l}\text { No physical disability that } \\
\text { limit participation in activities }\end{array}$ & Not applicable & Not applicable & Not applicable \\
\hline
\end{tabular}

Ref: * Tellevik et al., 2009, **ICD-10.

For the purpose of this study, the functional levels were consolidated:

Physical capacity (1-8): $1-3=$ severe, $4-5=$ moderate, $6-8=$ mild difficulty .

Communication (1-6): $1-2$ = severe, $3-4=$ moderate, $5-6=$ mild difficulty.

Vision (1-5): 1-2 = severe, 3 = moderate, $4-5=$ mild difficulty.

\section{REFERENCES}

Adolfsson M. Applying the ICF-CY to identify everyday life situations of children and youth with disabilities, in School of Education and Communication, Jönköping University: Jönköping 2011.

[2] Guralnick MJ. Connections between mental health and peer relationships for young children with developmental delays, in Regional ISEI conference I.S.o.E. Intervention, Editor 2013; St Petersburg.

[3] Axelsson AK, Granlund M, Wilder J. Engagement in family activities: A quantitative, comparative study of children with profound intellectual and multiple disabilities and children with typical development Child: Care. Health Develop 2013; 39(4): 523-34.

http://dx.doi.org/10.1111/cch.12044

[4] Cowart BL, et al. Social skills and recreational preferences of children with and without disabilities. North Am J Psychol 2004; 6(1): 27-42.

[5] Luttropp A, Granlund M. Interaction - it depends - a comparative study of interaction in preschools between children with intellectual disability and children with typical development. Scand J Disability Res 2010; 12(3): 151-64. http://dx.doi.org/10.1080/15017410903175677

[6] Guralnick MJ. Early intervention approaches to enhance the peer-related social competence of young children with developmental delays. Infants Young Children 2010; 23(2): 73-83 http://dx.doi.org/10.1097/IYC.0b013e3181d22e14

[7] Granlund $M$, et al. Differentiating activity and participation of children and youth with disability in Sweden: A third qualifier in ICF-CY? Am J Phys Med Rehabilit 2012; 91(13): S84-S96. http://dx.doi.org/10.1097/PHM.0b013e31823d5376

[8] Wilder J. Proximal processes of children with profound multiple disabilities, in Psychology, Stockholm University: Stockholm 2008.

[9] Guralnick MJ, et al. Promoting the peer-related social development of young children with mild developmental delays: Effectiveness of comprehensive intervention. Am J Mental Retardat 2006; 111(5): 336-56. http://dx.doi.org/10.1352/08958017(2006)111[336:PTPSDO]2.0.CO;2 
[10] WHO, International Classification of Functioning, Disability and Health for Children and Youth (ICF-CY), Geneva: World Health Organization 2007.

[11] Eriksson L. Participation and disability - a study of participation in school for children and youth with disabilities, Stockholm: Karolinska institutet, Department of Woman and Child Health, Child and Adolescent Psychiatric Unit 2006.

[12] Simeonsson RJ, et al. Disability, health, secondary conditions and quality of life: Emerging issues in public health, in Issues in disability \& health. The role of secondary conditions \& quality of life, Simeonsson RJ, McDevitt LN, Ed. University of North Carolina: Chapel Hill: NC. 1999; pp. 239255.

[13] Maxwell G, Granlund M. How are conditions for participation expressed in education policy documents? A review of documents in Scotland and Sweden. Eur J Special Needs Educ 2011; 26(2): 251-72. http://dx.doi.org/10.1080/08856257.2011.563610

[14] Almqvist L, Uys CJE, Sandberg A. The concepts of participation, engagement and flow: A matter of creating optimal play experiences. South Afr J Occupat Therapy 2007; 37(3): 8-13.

[15] Piškur B, et al. Participation and social participation: are they distinct concepts? Clinical Rehabilitation 2013; (Early online August 29). http://dx.doi.org/10.1177/0269215513499029

[16] King G, et al. Out-of-school time activity participation profiles of children with physical disabilities: a cluster analysis. Child: care. Health Develop 2010; 36(5): 726-41. http://dx.doi.org/10.1111/j.1365-2214.2010.01089.x

[17] Heah $T$, et al. Successful participation: The lived experience among children with disabilities. Can J Occupat Therapy 2007; 74: 38-47.

http://dx.doi.org/10.2182/cjot.06.10

[18] Rosenbaum P, Gorter JW. The 'F-words' in childhood disability: I swear this is how we should think! Child: care. Health Develop 2012; 38(4): 457-63. http://dx.doi.org/10.1111/j.1365-2214.2011.01338.x

[19] Rosenbaum $P$, et al. A report: the definition and classification of cerebral palsy. Develop Med Child Neurol 2007; 49(s109): 8-14.

[20] Aicardi J, Bax M. Cerebral Palsy, in Diseases of the Nervous System in Childhood. Aicardi J, Ed. Mac Keith Press: London 1998; pp. 210-244.

[21] Beckung E, Hagberg G. Neuroimpairments, activity limitations, and participation restrictions in children with cerebral palsy. Develop Med Child Neurol 2002; 44(5): 30916.

http://dx.doi.org/10.1111/j.1469-8749.2002.tb00816.x

[22] Axelsson AK, Wilder J. Frequency of occurrence and child presence in family activities: A quantitative, comparative study of children with profound intellectual and multiple disabilities and children with typical development. Int $\mathrm{J}$ Develop Disabilit 2013; 59(1): 1-18.

[23] Tellevik JM, Elmerskog B. Activitybased intervention for multiple-disabled visually impaired people. $\mathrm{Br} J$ Visual Impairment 2009; 27(3): 204-20. http://dx.doi.org/10.1177/0264619609106361

[24] Raghavendra $P$, et al. School participation and social networks of children with complex communication needs, physical disabilities, and typically developing peers. Augmentative Alternative Commun 2012; 28(1): 33-43. http://dx.doi.org/10.3109/07434618.2011.653604

[25] Law $M$, et al. Participation of children with physical disabilities: relationships with diagnosis, physical function, and demographic variables. Scand J Occup Ther 2004; 11(4): 156-62.

http://dx.doi.org/10.1080/11038120410020755
[26] Lee AM. Using the ICF-CY to organise characteristics of children's functioning. Disabil Rehabil 2011; 33(7): 605-16. http://dx.doi.org/10.3109/09638288.2010.505993

[27] Simeonsson RJ. Defining and classifying disability in children, in Workshop on Disability in America, a New Look: summary and papers, Field MJ, Jette AM, Martin L, Eds. The National Academies Press Washington, DC 2006; pp. 67-87.

[28] Harty M, Joseph L, Wilder J. Social networks and support of families: towards positive family functioning. South Afr J Occupat Therapy 2007; 37(3): 18-23.

[29] Bronfenbrenner U. Ecological systems theory. Ann Child Develop 1989; 22: 723-42.

[30] Bornman J, Rose J. Believe that all can achieve. Increasing classroom participation in learners with special support needs, Pretoria: Van Shaik 2010.

[31] Cardol M, De Jong BA, Qard CD. On autonomy and participation in rehabilitation. Disabil Rehabil 2002; 24(18): 970-74.

http://dx.doi.org/10.1080/09638280210151996

[32] Government office. Swedish disability policy. 2004 Dec 10, 2010 [cited 2011 Apr 3 www.regeringen.se/sb/d/2197/ a/15254].

[33] Stenhammar A-M, Lyssna på mig! Barn \& ungdomar med funktionsnedsättningar vill vara delaktiga $i$ möten med samhällets stödsystem En systematisk kunskapsöversikt [Listen to me! Children \& young people with disabilities want to be involved in meetings with community support systems. A systematic review], in School of Health and Society, [Master thesis]. Halmstad University: Halmstad 2010.

[34] SOSFS, Ändring i föreskrifterna och allmänna råden (SOSFS 2007:10) om samordning av insatser för habilitering och rehabilitering [Changes in regulations and guidelines (SOSFS 2007:10) coordinating the efforts of habilitation and rehabilitation], Socialstyrelsen [The Swedish National Board of Health and Welfare] 2008; 20.

[35] PSM, Rullstolsmobility. Ett samverkansprojekt där målet är att säkra barn och ungdomars aktivitet, delaktighet och involvering i livssituationer.[Wheelchair mobility. A collaborative project aiming to ensure children and young people's activity, participation and involvement in life situations.], 2011, Specialpedagogiska Skolmyndigheten (SPSM) [National Agency for Special Needs Education and Schools], Riksförbundet för Rörelsehindrade Barn och Ungdomar (RBU) [National Association for Disabled Children and Young People], Synskadades Riksförbund (SRF) [Visually Impaired Association], and Allmänna Arvsfonden [The Swedish Inheritance Fund Commission].

[36] Cieza A, et al. ICF linking rules: an update based on lessons learned. J Rehabilit Med 2005; 37(4): 212-18. http://dx.doi.org/10.1080/16501970510040263

[37] Simeonsson RJ, et al. Developmental and health assessment in rehabilitation with the ICF for Children and Youth, in Rehabilitation and health assessment. Applying ICF guidelines, Mpofu E, Oakland T, Ed. Springer: New York 2010; pp. 27-46.

[38] Klang Ibragimova $\mathrm{N}$, et al. Using content analysis to link texts on assessment and intervention to the International Classification of Functioning, Disability and Health - version for Children and Youth (ICF-CY). J Rehabilit Med 2011; 43(8): 728-33.

http://dx.doi.org/10.2340/16501977-0831

[39] Colver A. What are we trying to do for disabled children? Curr Paediatr 2006; 16(7): 501-505. http://dx.doi.org/10.1016/j.cupe.2006.08.014

[40] Imms C. Children with cerebral palsy participate: A review of the literature. Disabil Rehabil 2008; 30(24): 1867-84. http://dx.doi.org/10.1080/09638280701673542

[41] Shogren $\mathrm{KA}$, et al. Understanding the construct of selfdetermination: Examining the relationship between the Arc's 
self-determination scale and the American institutes for research self-determination scale. Assess Effect Intervent 2008; 33: 94-107. http://dx.doi.org/10.1177/1534508407311395

[42] Carter EW, et al. Promoting self-determination for transitionage youth: Views of high school general and special educators. Exceptional Children 2008; 75(1): 55-70.

[43] UNESCO, Open file on inclusive education: support materials for managers and administrator, Paris: UNESCO 2003.

[44] Schenker R, Coster WJ, Parush S. Participation and activity performance of students with cerebral palsy within the school environment. Disabil Rehabil 2005; 27(10): 539-52. http://dx.doi.org/10.1080/09638280400018437

[45] Bedell G, Cohn ES, Dumas HM. Exploring parents' use of strategies to promote social participation of school-age children with acquired brain injuries. Am J Occup Ther 2005; 59(3): 273-84.

http://dx.doi.org/10.5014/ajot.59.3.273

[46] Majnemer A, et al. Determinants of life quality in school-age children with cerebral palsy. J Pediatr 2007; 151(5): 470475.e3.

[47] Perenboom RJM, Chorus AMJ. Measuring participation according to the International Classification of Functioning, Disability and Health (ICF). Disabil Rehabil 2003; 25(11-12): 577-87.

http://dx.doi.org/10.1080/0963828031000137081
[48] Bornman J, Murphy J. Using the ICF in goal setting: Clinical application using Talking Mats. Disabil Rehabil Assist Technol 2006; 1(3): 145-54. http://dx.doi.org/10.1080/17483100612331392745

[49] Lidström H. Möjligheter och hinder för barn med funktionshinder att vara delaktiga inför en intervention [Possibilities and obstacles for children with disabilities to participate in intervention planning], in Institutionen för Samhälls- och Beteendevetenskap, [Master thesis]. Mälardalens högskola: Västerås 2005.

[50] SFS. Education act. Swedish governement offices. 2010; 800.

[51] UN, UN Convention on the Rights of the Child, United Nations: New York 1989.

[52] Badley EM. Enhancing the conceptual clarity of the activity and participation components of the International Classification of Functioning, Disability, and Health. Social Sci Med 2008; 66(11): 2335-45. http://dx.doi.org/10.1016/j.socscimed.2008.01.026

[53] Lebeer $\mathrm{J}$, et al. Identifying special educational needs: putting a new framework for graded learning support to the test. Eur J Special Needs Educ 2010; 25(4): 375-87. http://dx.doi.org/10.1080/08856257.2010.513542

[54] Reindal SM. Disability, capability, and special education: towards a capability-based theory. Eur J Special Needs Educ 2009; 24(2): 155-68. http://dx.doi.org/10.1080/08856250902793610

(c) 2014 Adolfsson et al.; Licensee Lifescience Global.

This is an open access article licensed under the terms of the Creative Commons Attribution Non-Commercial License (http://creativecommons.org/licenses/by-nc/3.0/) which permits unrestricted, non-commercial use, distribution and reproduction in any medium, provided the work is properly cited. 